\title{
80. výročí založení Československé a České kardiologické společnosti
}

\author{
Michael Aschermann, Jiří Widimský* \\ 2. interní klinika, Všeobecná fakultní nemocnice a 1. lékařská fakulta Univerzity Karlovy, *Klinika kardiologie, Institut klinické \\ a experimentální medicíny, Praha, Česká republika
}

Adresa: prof. MUDr. Michael Aschermann, DrSc., FESC, FACC, 2. interní klinika, VFN a 1. LF UK, U nemocnice 2, 12808 Praha 2, Česká republika, e-mail: mascher@vfn.cz

\section{Předsedové \\ Československé \\ a České kardiologické \\ společnosti}

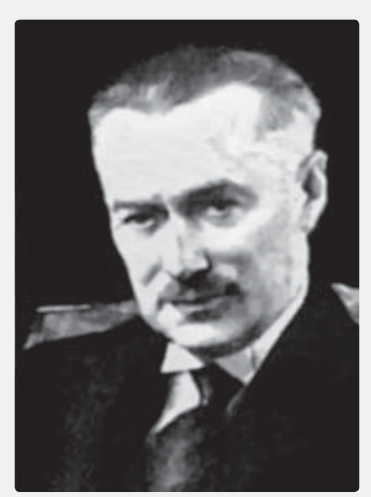

1929-1938

Prof. MUDr. Václav Libenský

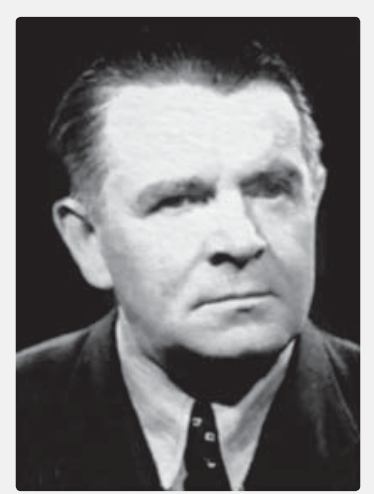

1938-1942 a 1951-1955

Prof. MUDr. Klement Weber

\section{Založení společnosti a její vedení}

$\mathrm{V}$ roce 2009 slaví naše odborná kardiologická společnost 80. výročí svého založení. Československá kardiologická společnosti (ČKS) byla založena 13. prosince 1929 v Praze; nejvíce se o její vznik zasloužil Václav Libenský, který byl jejím prvním prezidentem. Je jistě pozoruhodné, že ČKS vznikla jako druhá kardiologická společnost v Evropě po Německé kardiologické společnosti (založené $\mathrm{v}$ roce 1927) a třetí na světě po American Heart Association (založené v roce 1924). Teprve za pět let po ČKS vznikly další kardiologické společnosti v Argentině, Itálii a v Nizozemsku. V roce 1937 byly založeny kardiologické společnosti ve Francii a Velké Británii. První výbor ČKS měl zajímavé interdisciplinární složení, všichni jeho členové byli Češi. Prezidentem byl již zmíněný profesor Václav Libenský, jednatelem byl zvolen kardiolog Josef Brumlík, který později emigroval před nacismem do USA a pak do Mexika, kde patř̌il mezi zakladatele Národního kardiologického ústavu v Mexico City. Místopředsedové byli tř̌i - farmakolog Bohuslav Bouček, fyziolog Antonín Hanák a internista Kristián Hynek. Pokladníkem byl patolog Václav Jedlička. Interdisciplinární složení prvního výboru je patrné $\mathrm{z}$ přehledu dalších členů výboru: porodník Josef Jerie, chirurg Arnold Jirásek, kardiolog Stanislav Mentl, balneolog Vladislav Mladějovský, internista Jan Řehoř, patofyziolog Alois Velich a internista-kardiolog Klement Weber. V roce 1932 se vzdal funkce ve výboru A. Velich a na jeho místo byl zvolen slovenský internista-kardiolog J. Sumbal z Bratislavy, který zůstal členem výboru ve funkci místopředsedy i po roce 1939 v období druhé světové války.

Již v roce 1933 se konal v Praze první mezinárodní kardiologický kongres; jeho prezidentem byl profesor Václav Libenský, čestným předsedou byl prezident Československé republiky Tomáš G. Masaryk. Mezi členy čestného předsednictva byli významní představitelé anglické kardiologie - T. Lewis a francouzské kardiologie H. Vaquez. Kongresu se účastnilo 200 lékařủ, z nichž 50 bylo ze zahraničí, nejvíce z Francie a Polska, další účastníci byli z Anglie, Argentiny, Belgie, Nizozemska, Itálie, Rumunska, Španělska a Švýcarska. Stojí jistě za připomenutí, že Evropská kardiologická společnost (založená 2. 9.1950 v Pař́ǐii) a Mezinárodní kardiologická společnost (založená 1952) vznikly až téměř 20 let po uspořádání tohoto mezinárodního kardiologického kongresu v Praze. Profesor Jiří Widimský senior připomíná, že v roce 1974 na Světovém kardiologickém kongresu v Buenos Aires byla v kongresovém bulletinu na první straně fotografie panoramatu Prahy a text o kongrese, který se u nás konal před 45 lety.

Profesor Václav Libenský zemřel náhle v roce 1938, ve funkci předsedy ho nahradil profesor Klement Weber. V roce 1939 se konal v Praze druhý kardiologický kongres, ovšem již za složité politické situace. 

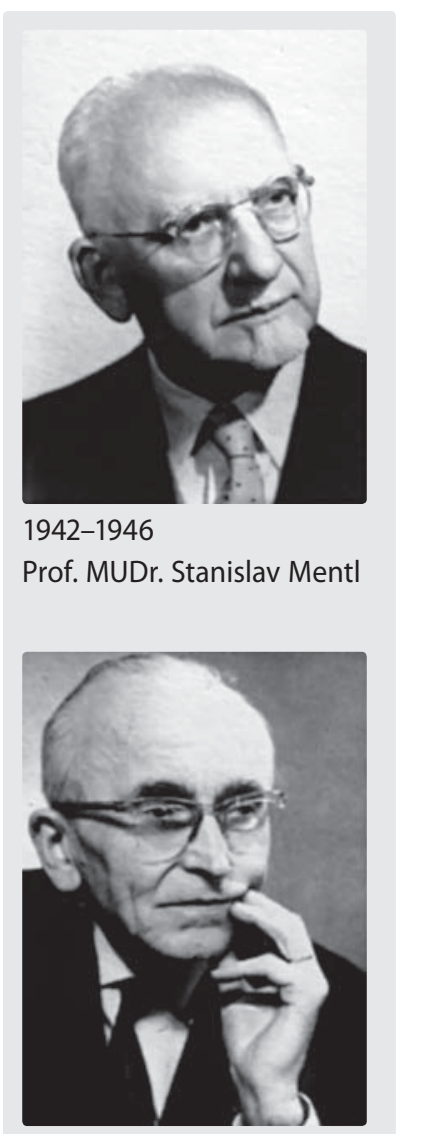

1946-1951

Prof. MUDr. František Herles

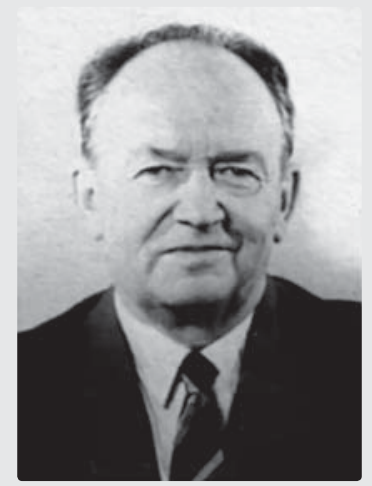

1955-1959

Prof. MUDr. Vladimír Haviar

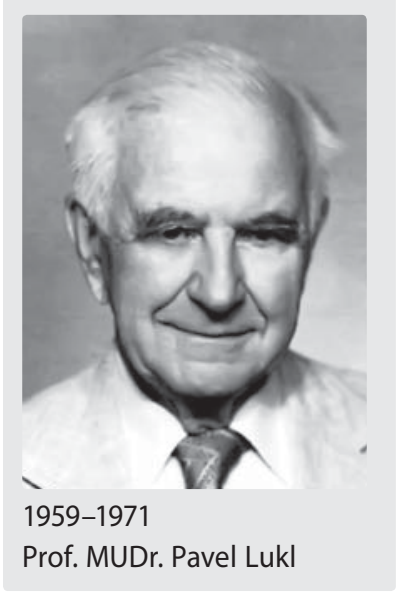

Od roku 1942 byl prezidentem ČKS profesor Stanislav Mentl (1942-1946), následovali pak profesoři František Herles (1946-1951), znovu Klement Weber (1951-1955), dále profesoři Vladimír Haviar (1955-1959) a Pavel Lukl (1959-1968). Následovali další předsedové - profesor Pavel Lukl (1969-1971), po něm profesor Zdeněk Reiniš (1971-1981) a profesor Vladimír Dufek (1981-1990). V roce 1968 v souvislosti s federativním uspořádáním naší republiky vznikla v Bratislavě samostatná Slovenská kardiologická společnost (SKS). Jejími předsedy byli postupně profesor Vladimír Haviar (1968-1973), profesor Michal Ondrejička (1973-1978) a profesor Ján Gvozdják (1978-1990).

Prvním předsedou ČKS po „sametové revoluci“ v roce 1989 se stal profesor Vladimír Staněk (1990-1995), následovali profesoři Roman Čerbák (1995-1999) a Jaromír Hradec (1999-2004). V 90. letech po rozdělení Československa na dva státy vznikly znovu dvě samostatné společnosti a vzájemná spolupráce ČKS a SKS pokračuje dále na mnoha úrovních. Tradiční je účast českých kardiologů na výročním sjezdu SKS, a naopak slovenští kardiologové se v počtu několika set účastní výročního sjezdu ČKS. Tradiční je blok Slovenské kardiologické společnosti na kongrese ČKS v Brně, a naopak blok ČKS na kongrese SKS na Slovensku. Vzájemné styky jsou velmi aktivní také na úrovni pracovních skupin. Pracovní skupina ČKS Arytmie a kardiostimulace pořádá společná česká a slovenská symposia na kongresech obou společností. Aktivní výměna zkušeností probíhá také v dalších pracovních skupinách, příkladem mohou být intervenční kardiologové.

Přehled pracovních skupin ČKS: Akutní kardiologie, Ambulantní kardiogie, Arytmie a trvalá kardiostimulace, Echokardiografie, Chlopenní a vrozené srdeční vady v dospělosti, Intervenční kardiologie, Kardiovaskulární farmakoterapie, Kardiovaskulární rehabilitace, Nukleární kardiologie, Ošetřovatelství v kardiologii, Pediatrická kardiologie, Plicní cirkulace, Preventivní kardiologie, Srdeční selhání.

\section{Mezinárodní kongresy a symposia do roku 1989}

Při pohledu do historie je nutné vyzdvihnout některé významné mezinárodní akce, které byly uspořádány $\mathrm{v}$ Československu a později v České republice. První kongres Evropské kardiologické společnosti (European Society of Cardiology, ESC) se konal v roce 1952 v září v Londýně, jeho prezidentem byl Sir John Parkinson. Již v roce 1964 byla tehdejší Československá kardiologická společnost pověřena uspořádáním IV. evropského kardiologického kongresu. Nesmírná čest a velká odpovědnost pro pořadatele - české kardiology! Je nutné připomenout, že až do roku 1988 se konaly evropské kongresy pouze jednou za čtyři roky. $\mathrm{Na}$ rozdíl od současných kongresů byla $v$ té době organizace i sestavení programu převážně v rukou příslušné národní kardiologické společnosti. Prezidentem IV. kongresu ESC v Praze v roce 1964 byl profesor Pavel Lukl; kongresu se účastnilo 1500 odborníků z 31 zemí, celkově se ho účastnilo včetně doprovodu 2200 osob. Přihlášeno bylo 525 sdělení (můžeme srovnávat s téměř 10000 přihlášenými sděleními na kongresy ESC v posledních letech). Kongres se konal v pražském Rudolfinu, některé sekce probíhaly na Právnické fakultě Univerzity Karlovy.

Jedním z účastníků tohoto kongresu byl profesor Otto Klein, který jako první na světě použil v Praze na tehdejší německé fakultě v roce 1929 srdeční katetrizaci k získání údajů o funkci srdce - měřil minutový srdeční výdej podle Ficka. Přestože výsledky své práce uveřejnil ve stejném roce v časopise Münchener Medizinische Wochenschrift nebyl navržen na Nobelovu cenu; ta byla za srdeční katetrizace udělena v roce 1956. Přímým pamětníkem tohoto významného lékaře je profesor Jiří Widimský, který se seznámil s profesorem Kleinem v roce 1964 právě v Praze. V článku z roku 2004 uvádí, že setkání bylo velmi srdečné a př́ijemné, profesor Klein při rozhovoru hodnotil velmi kladně úroveň českých a slovenských kardiologů.

U př́ležitosti 50. výročí založení ČKS v roce 1979 byla v Praze uspořádána celodenní odborná akce, jejíž program byl rozdělen do čtyř bloků: a) Ateroskleróza, koordinátor Zdeněk Reiniš, b) Ischemická choroba srdce včetně arytmií a srdečního selhání, koordinátor Vladimír Dufek, c) Arteriální a plicní hypertenze, koordinátor Jiří Widimský, d) Kardiochirurgie, koordinátor Juraj Fabián.

Z dalších významných mezinárodních akcí bylo v Praze v roce 1959 uspořádáno symposium o patogenezi hypertenze 


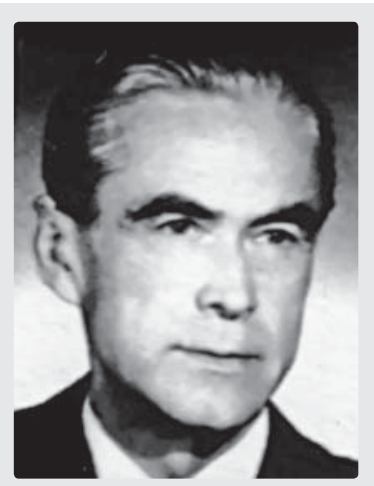

1971-1981

Prof. MUDr. Zdeněk Reiniš, DrSc.

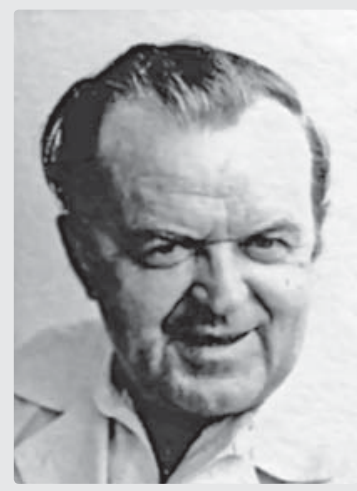

1981-1990

Prof. MUDr. Vadimír

Dufek, CSc.

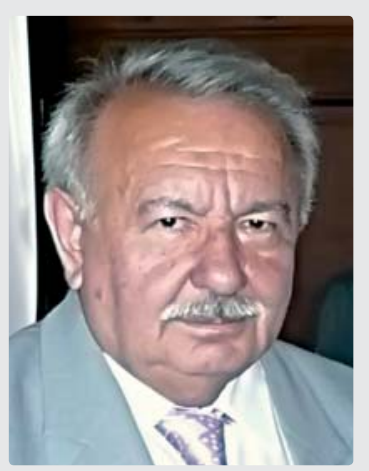

1990-1995

Prof. MUDr. Vladimír Staněk, CSc.

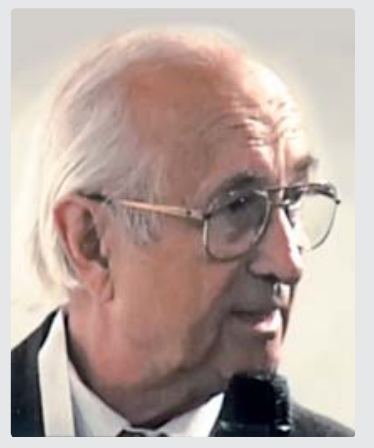

1995-1999

Prof. MUDr. Roman

Čerbák, CSc. (ve spolupráci se Světovou zdravotnickou organizací), byla to první významná mezinárodní kardiologická akce od roku 1948. Na Slovensku se konalo ve Sliači v roce 1966 mezinárodní symposium „Epidemiologie aterosklerózy a předčasného infarktu myokardu“, o rok později se konal v Bratislavě kardiologický sjezd s mezinárodní účastí. V roce 1970 se konalo ve Sliači mezinárodního symposium "Hypertrofie myokardu“. $\mathrm{V}$ Bratislavě se opakovaně konala mezinárodní symposia o tělesném cvičení a kardiovaskulární funkci, naposledy v roce 1989. Pod vedením profesora Gvozdjáka uspořádali slovenští kardiologové $\mathrm{v}$ roce 1985 v Bratislavě mezinárodní symposium o kardiomyopatiích. V roce 1988 uspořádala ESC ve spolupráci s ČKS v Bratislavě odborný seminář na téma: „Recent advances in Cardiology".

Mezi významné mezinárodní akce patřila symposia o plicní cirkulaci, pořádaná Československou společností pro fyziologii a patologii dýchání spolu s ČKS, pod záśtitou ESC. Ta se konala v Praze v pětiletých odstupech celkem sedmkrát - v letech 1969, 1974, 1979, 1984, 1989, 1994 a 1999 (koordinátoři Jiř́i Widimský, Alois Ouředník, Jan Herget). Symposia měla vždy mimořádně kvalitní mezinárodní účast, prvního setkání se např́klad účastnil aktivně nositel Nobelovy ceny za srdeční katetrizace André Cournand z New Yorku.

Není možné vynechat také mezinárodní angiologické kongresy, které se konaly v Praze dvakrát: v roce 1961 to byl IV. mezinárodní angiologický kongres (prezidentem kongresu byl profesor Bohumil Prusík), v roce 1978 pak XI. angiologický kongres (prezident profesor Zdeněk Reiniš). Tento kongres organizovala $\mathrm{v}$ té době existující angiologická sekce Československé kardiologické společnosti ve spolupráci s Mezinárodní angiologickou unií.

\section{Mezinárodní kongresy a symposia po roce 1989}

Po roce 1989 došlo k ohromnému nárůstu počtu pořádaných domácích i mezinárodních symposií a kongresů, postupně jsme se prosadili jako organizátoři řady akcí ESC; vybíráme $\mathrm{z}$ nich ty nejvýznamnější.

Doposud největší mezinárodní akcí byl světový a současně evropský kongres o hypertenzi „Hypertension Prague 2002“, konaný v Praze v červnu 2002 za účasti téměř
8000 odborníků. Pořadateli byli Česká společnost pro hypertenzi, European Society for Hypertension a International Society for Hypertension. V roce 1996 uspořádali v Plzni profesor Jaroslav Šimon s profesorkou Hanou Rosolovou symposium pracovní skupiny ESC pro prevenci a epidemiologii. O rok později se v Praze konala „15. evropská konference Mezinárodní společnosti neinvazivní kardiologie“, hlavním organizátorem byl profesor Jaromír Hradec. Postgraduální kurs ESC na téma „Srdeční selhání na začátku 3. tisíciletí" se uskutečnil v roce 2000 v Brně a hlavními organizátory byli profesoři Jiří Toman a Jaromír Hradec.

V roce 2005 se v Praze uskutečnil „75. evropský kongres o ateroskleróze“, pořádaný Evropskou společností pro aterosklerózu, ve spolupráci s Českou společností pro aterosklerózu. Z české strany byli hlavními organizátory profesoři Richard Češka a Rudolf Poledne.

Především zásluhou profesora Petra Widimského se v Praze opakovaně uskutečnila mezinárodní symposia s problematikou invazivní a intervenční kardiologie „INTERCATH“; všechna tato setkání přilákala řadu špičkových intervenčních kardiologů z Evropy i ze zámoří. V roce 2005 se toto symposium konalo při prŕležitosti 75. výročí prvních pravostranných katetrizací na světě, které provedl v Praze profesor Otto Klein v roce 1929.

Intervenční kardiologové pořádají akce velmi často; symposia s mezinárodní tradiční účastí pod záštitou ESC uspořádal opakovaně profesor Jan Vojáček. Také pracoviště pražského IKEM je centrem, ve kterém se na seminárích intervenční kardiologie setkávají kardiologové i sestry pravidelně, „duší těchto setkání je MUDr. Michael Želízko se spolupracovníky. Tradicí se staly meetingy invazivních a intervenčních kardiologů na řadě dalších míst $v$ České republice, připomeneme obě pracoviště brněnská (FN u sv. Anny a FN Brno-Bohunice), dále FN Motol v Praze, Hradci Králové, Olomouci, Třinci, Ústí nad Labem a VFN Praha. Také arytmologové jsou $\mathrm{v}$ pořádání vědeckých akcí velmi aktivní; již sedmkrát se konalo v Praze setkání „Prague Workshop on Catheter Ablation with Live Demonstration“, pořádané IKEM, ve spolupráci s pracovní skupinou Arytmie a kardiostimulace ČKS. Největšími mezinárodními kongresy, které jsme pořádali v Praze společně s ESC a Evropskou asociací srdečního 


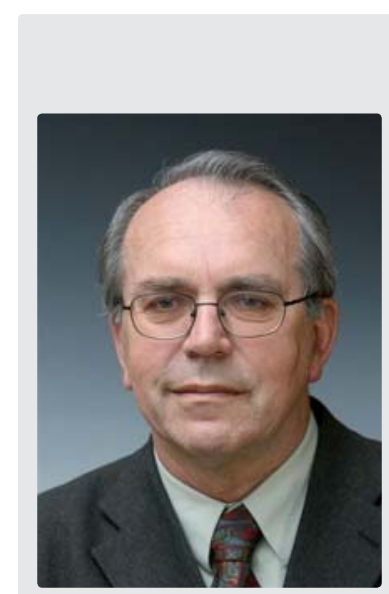

1999-2004

Prof. MUDr. Jaromír Hradec, CSc.

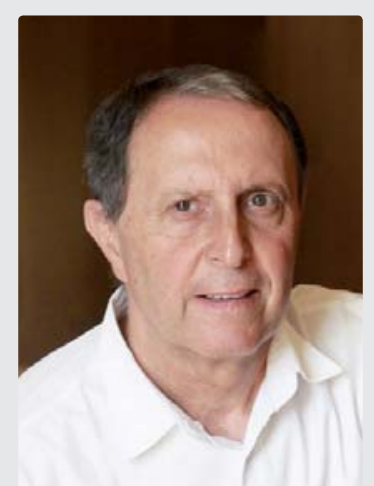

2005-2008

Prof. MUDr. Michael Aschermann, DrSc.

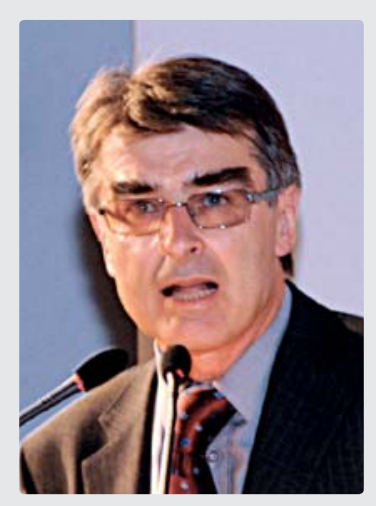

2008-2011

Doc. MUDr. Václav Chaloupka, CSC. rytmu, byl „EUROPACE“ v roce 2005 (z české strany byli hlavními organizátory docent Miloš Táborský, docent Petr Neužil a profesor Josef Kautzner); v následujícím roce pak „Acute Cardiac Care“ (MUDr. Petr Jánský a spol.) a „EUROECHO“ (za českou stranu byla hlavní organizátorkou MUDr. Hana Skalická). Všech těchto symposií se účastnilo více než 1500 lékař̀ Z celého světa; představitelé ESC tyto akce hodnotili velmi kladně. $Z$ dalších aktivit je jistě vhodné připomenout tradiční setkání kardiologů věnujících se akutní kardiologii v Karlových Varech (MUDr. Petr Jánský a pracovní skupina Akutní kardiologie); již sedm ročníků oblíbeného symposia „PRAGUECHO“ - obvykle s kvalitní mezinárodní účastí - jeho zakladatelem je profesor Aleš Linhart; dále „Rokitanského den kardiologư“ v Hradci Králové (profesor Jan Vojáček). Připomeneme si i mezinárodní akci kardiochirurgů - „International Postgraduate Course in Aortic Root Surgery“. Další desítky symposií a seminářů jsou pravidelně pořádány ostatními pracovními skupinami ČKS.

Dětské kardiocentrum v Praze pořádá každoročně od roku 1983 mezinárodní semináře; v roce 1989 se konal v Praze „Evropský sjezd pediatrických kardiologü“, hlavním organizátorem byl profesor Milan Šamánek.

\section{Vývoj kardiologické péče po realizaci studií PRAGUE}

Až do roku 1989 existovalo v České republice jen pět kardiocenter pro kardiochirurgii (Institut klinické a experimentální medicíny v Praze, Fakultní nemocnice v Praze 2, Fakultní nemocnice v Hradci Králové, Fakultní nemocnice v Brně a Dětské kardiocentrum v Praze-Motole). V Brně provedl profesor Jiří Navrátil první operaci v mimotělním oběhu u nás, v Hradci Králové pak profesor Jan Bedrna byl prvním naším kardiochirurgem, který provedl operaci mitrální vady. K zásadní změně celého vývoje péče v oboru kardiologie vedl kromě vzniku koronárních jednotek rozvoj intervenční kardiologie, v České republice s tím související realizace studií PRAGUE. O jejich historii a výsledcích se zmiňuje v tomto čísle Cor et Vasa jejich „duchovní otec", profesor Petr Widimský. Nový systém péče o nemocné s akutními koronárními syndromy (AKS) vedl postupně ke vzniku celkem
22 kardiologických pracovišt' s katetrizačními sály a pracovními týmy, které poskytují „nonstop“ službu pro diagnostiku a léčbu AKS. Je samozřejmé, že na těchto pracovištích postupně vyrostla celá generace mladších kardiologů. Počet atestovaných specialistů v oboru kardiologie tak narůstal přibližně o 50 lékařuo za rok. Uvedený systém péče umožnil také provedení projektu „Czech Registr“. Výsledky sledování nemocných s AKS po dobu jednoho měsíce ve vybraných oblastech České republiky přinesly řadu zajímavých údajů a byly opakovaně prezentovány a publikovány $\mathrm{v}$ našem i $\mathrm{v}$ zahraničním písemnictví. Kardiochirurgických pracovišt je celkem 12, ve dvou $\mathrm{z}$ nich se provádějí vedle celého spektra výkonů také srdeční transplantace.

Nesmírný význam pro dětskou kardiologii mělo založení Dětského kardiocentra v Praze-Motole v roce 1977. Práce tohoto kardiocentra pod vedením zakladatele a dlouholetého přednosty profesora Milana Šamánka změnila zásadně systém péče o děti s vrozenými srdečními vadami v celém Československu a mělo významnou roli v rozvoji dětské kardiologie i kardiochirurgie.

\section{K práci výboru České kardiologické společnosti}

Výbor ČKS tvoří celkem 13 kardiologů, kteří jsou voleni každé tři roky. Systém práce celé ČKS je řízen Stanovami, nejvyšším orgánem je pak Valná hromada společnosti, která se koná pravidelně na výročním sjezdu ČKS. Výbor se podílí na práci v mnoha oblastech, hlavní akcí je tradiční výroční sjezd ČKS, který má především edukační charakter; program se připravuje $\mathrm{z}$ velké části $\mathrm{v}$ jednotlivých pracovních skupinách, ale prostor je věnován také volným sdělením, posterům a firemním symposiím. V posledních letech přesáhl počet účastníků kongresu 4000 , a je tak největší odbornou akcí v České republice. Výbor ČKS připravuje obvykle několik reprezentativních bloků včetně symposií a s účastí pozvaných zahraničních kapacit. Je možné připomenout, že v posledních deseti letech jsme na kongrese ČKS mohli přivítat několik prezidentů ESC a celou řadu významných špiček nejen evropské, ale i americké a kanadské kardiologie a také mnoho českých kardiologů, kteří od roku 1968 působí velmi úspěšně na zahraničních pracovištích. Jmenovat 
Členové výboru

Evropské kardiologické společnosti

z České kardiologické společnosti

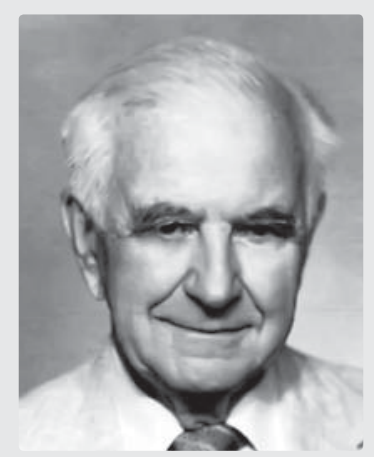

Prof. MUDr. Pavel Lukl (prezident)

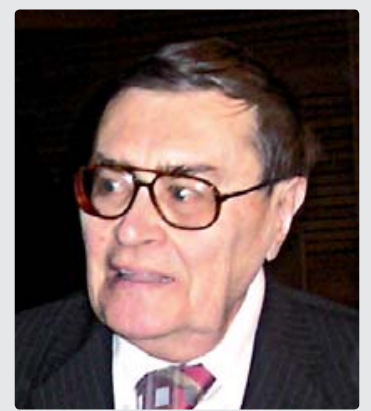

Prof. MUDr. Jiří Widimský, DrSc (viceprezident)

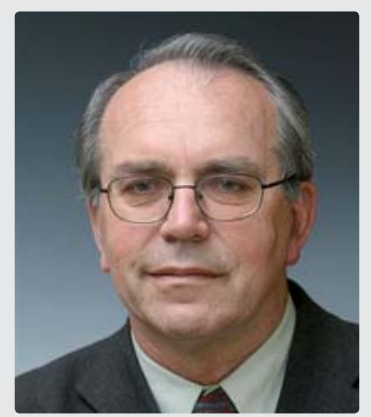

Prof. MUDr. Jaromír Hradec, CSc. (člen výboru)

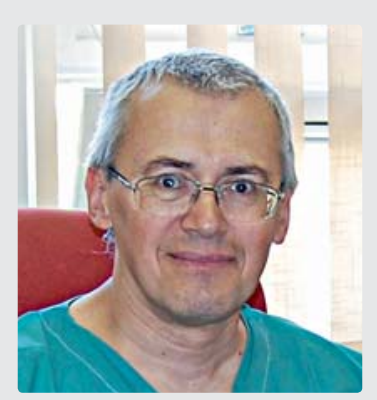

Prof. MUDr. Petr Widimský, DrSc (viceprezident) můžeme např́íklad Pavla Hameta, Otto Küchela, Jiřího Fröhlicha a Jiřího Fodora z Kanady, Alexandra Schirgera, Tomáše Klímu a L. P. Nováka z USA, Marka Malíka a Jaroslava Starka z Velké Británie, Pavla Jerieho ze Švýcarska, S. Dauma z Německa ... a byla zde i řada dalších. Druhou větší akcí pořádanou výborem ČKS jsou Kardiologické dny na Homolce; jejich původní název byl „Výzkumné kardiologické dny“ a náplní byla $\mathrm{z}$ větší části experimentální kardiologie. Vzhledem $\mathrm{k}$ tomu, že účast se stále zmenšovala, došlo k zásadní změně; hlavním tématem tohoto setkání jsou bloky věnované postgraduálnímu vzdělávání. Velmi dobrá účast posledních ročníků svědčí o tom, že tato „forma“ je pro mladé kardiology přitažlivá. Nutné je také zmínit „Dny mladých kardiologư“, které se konají již mnoho let a jejichž konání bylo $\mathrm{v}$ minulosti spojeno se jménem MUDr. Petra Frídla. Výbor ČKS v letošním roce rozhodl, že tradiční soutěž mladých kardiologů bude od roku 2010 přesunuta do programu výročního sjezdu ČKS, tj. bude uspořádána podobně, jako je tomu při sjezdech ESC. Podrobnosti budou zveřejněny $\mathrm{v}$ následujícím čísle tohoto časopisu. Členové výboru se také podílejí na řadě dalších aktivit ve vztahu k Ministerstvu zdravotnictví České republiky (akreditace pracovišt', vzdělávání v kardiologii), jednání s pojištovnami, jednání s ostatními odbornými společnostmi a podobně. ČKS věnuje každým rokem významnou finanční pomoc ze svých prostředků na podporu mladých kardiologů, funguje nyní inovovaný systém grantů ČKS; v minulých letech byl každým rokem výzkum podporován částkou až jednoho milionu Kč. Připomeňme také tradici udělování „čestných členství ČKS“ významným českým kardiologům. V posledních letech vyjadřujeme úctu těm nejlepším osobnostem české kardiologie - udělováním zlaté medaile profesora Libenského. Slavnostní předání se uskutečňuje vždy v červnu na zámku v Poděbradech. Jména dosavadních šesti laureátů této medaile a jejich fotografie jsou na konci článku.

\section{Cor et Vasa}

Časopis naší společnosti není třeba představovat, $\mathrm{v}$ letošním roce vychází jeho jednapadesátý ročník a redakční rada i nakladatelství Medical Tribune vyvíjejí trvalou snahu o to, aby jak obsah, tak celková kvalita časopisu byla co nejvyšší. V současné ekonomické situaci to není snadný úkol především pro nakladatele, mírnou změnu pocítíme již v prrištím roce, kdy sice vyjde opět celkem 12 čísel, ale čtyřikrát ve formě dvojčísel. Z hlediska kvality obsahu ponecháváme hodnocení na vás, vedení redakce časopisu chce mít úroveň co nejvyšší, hodně to závisí ale i na vás, autorech. Chceme poděkovat všem autorům a také recenzentům, kteří k tomu, aby byl časopis kvalitní, významně přispívají. Dík zde patří i Mgr. Jaroslavu Hořejšímu a Mgr. Jiřině Kadeřávkové za spolupráci, která je pro úroveň vydávaného časopisu zcela zásadní.

\section{Čeští kardiologové ve výboru Evropské kardiologické společnosti}

Ve výboru ESC působili za celou její historii celkem čtyři čeští kardiologové. Zatím jediným z nich, který se stal prezidentem ESC, byl profesor Pavel Lukl, který vedl ESC v letech 1968-1972, pak byl zvolen v Madridu čestným předsedou ESC. Profesor Jiří Widimský byl viceprezidentem ESC v letech 1980-1984, předtím byl v letech 1976-1980 členem výboru ESC. Profesor Jaromír Hradec byl členem výboru ESC v letech 2000-2002, v roce 2004 byl na kongrese ESC v Mnichově nově zvolen do výboru ESC profesor Petr Widimský, ve výboru byl pak ve funkci viceprezidenta. $\mathrm{V}$ následujících volbách prezidenta elect ESC byl profesor Petr Widimský jedním ze tří kandidátů na nového prezidenta ESC; přes významnou podporu, které se mu dostalo od představitelů více než dvaceti národních kardiologických společností z celé Evropy, do funkce bohužel nebyl zvolen. Profesor Josef Kautzner je v současné době pokladníkem výboru EHRA, je teda vy významné pozici v ESC.

Pro úplnost zmíníme také fakt, že v dřívějších letech byl součástí ČKS také obor angiologie, jehož představitelé dosáhli významných úspěchů na mezinárodní úrovni-zmíníme především profesora Bohumila Prusíka, který byl prezidentem Mezinárodní angiologické unie v letech 1961-1964, a profesora Zdeňka Reiniše, který byl rovněž prezidentem této unie v letech 1978-1982. MUDr. Karel Roztočil byl pak generálním sekretářem této unie v roce 2004-2006. Členy výboru $\mathrm{v}$ minulosti byli rovněž 


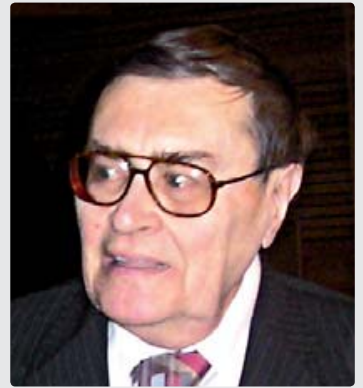

Prof. MUDr. Jiří

Widimský, DrSc.

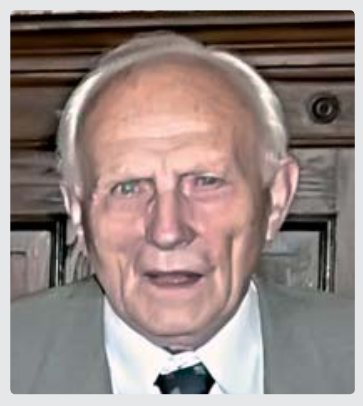

Prof. MUDr. Pavel Bravený, CSc.

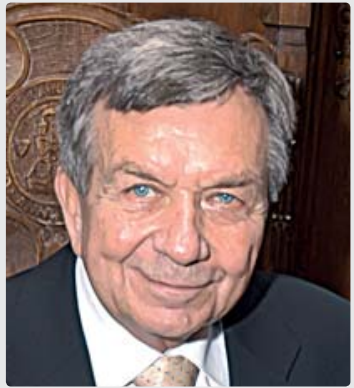

Prof. MUDr. Milan Šamánek, DrSc.

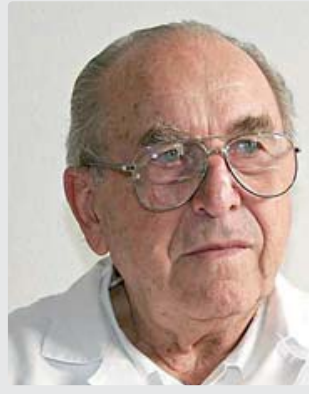

Doc. MUDr. Jiří Endrys, CSc.

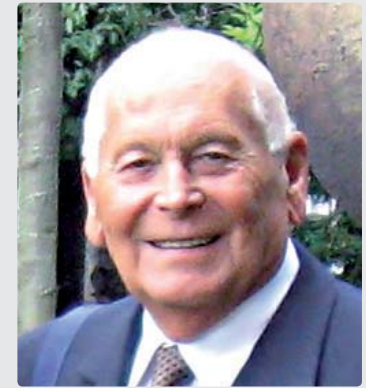

Prof. MUDr. Miloš

Štejfa, DrSc.

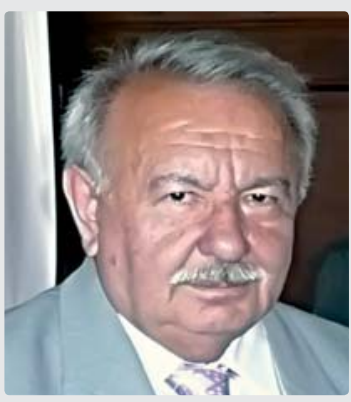

Prof. MUDr. Vladimír Staněk, CSc.
MUDr. Jiří Linhart a MUDr. Josef Pokorný. Významné postavení v Evropské společnosti pro hypertenzi má mnoho let profesorka Renata Cífková: byla členkou výboru v roce 1997, později se stala generálním sekretářem. MUDr. Petr Jánský byl členem výboru PS Acute Cardiac Care ESC.

Je třeba také připomenout naše zástupce ve Světové zdravotnické organizaci: profesora Zdeňka Fejfara a profesora Zbyňka Píšu, kteří vedli kardiovaskulární oddělení v Ženevě a snažili se významně podporovat mezinárodní styky naší kardiologie.

\section{Pro zájemce o podrobnější informace o historii ČKS}

Více z historie československé kardiologie lze nalézt ve zpravodaji Kardio z roku 1979, ve kterém je uveden článek profesora Zdeňka Reiniše o historii ČKS v letech 1929-1945 a sdělení profesora Haviara o historii slovenské kardiologie.

Ve zpravodaji Kardio v roce 1989 je téměř sto stran věnováno historii české a slovenské kardiologie spolu se zprávou o činnosti ČKS za období let 1929-1945 od profesora Reiniše; obsahuje také zprávu o činnosti SKS profesorů J. Gvozdjáka a I. Riečanského a řadu dalších příspěvků profesorů J. Procházky, F. Herlese, P. Lukla, V. Haviara, Z. Fejfara, B. Fleischhanse, J. Ulricha a M. Fejfušy.

Také v monografii profesora Zdenka Fejfara a spolupracovníků „Česká kardiologie a kardiologové“ je rozsáhlá kapitola o historii ČKS.

\section{Závěrem}

Je nepochybné, že u založení Československé kardiologické společnosti stály mimořádné osobnosti české medicíny. Během její osmdesátileté historie jsme zaznamenali řadu mezinárodních úspěchů. Bylo to jistě nesmírně obtížné především $\mathrm{v}$ době, která nepřála vzdělaným a charakterově čistým osobnostem. Mnozí z nich dokonce svou vlast opustili, většině z nich se podařilo dosáhnout v zahraničí významných postavení. Musíme si však vážit práce i těch, kteří zůstali „doma“ a v tom nemilosrdném režimu udržovali úroveň naší kardiologie na vysoké úrovni a dokázali se prosadit i na mezinárodním poli. Daří se to i nyní, v době, kdy účast na zahraničních kongresech je již běžná. Přiznejme si však, že aktivní účast není zdaleka na takové úrovni, abychom mohli být spokojeni. Je nepochybné, že prosadit se dnes v ohromné konkurenci k aktivní prezentaci na kongresy ESC a v USA není snadné. Ještě obtížnější je prosadit se do výboru ESC i jeho pracovních skupin. Chceme věřit, že z mladší generace kardiologů vyrostou nové osobnosti (se zkušenostmi ze zahraničních stáží), které budou pokračovat v tom nejlepším z tradic naší kardiologie.

$\mathrm{Na}$ úplný závěr poznámka: př́spěvek svým rozsahem neumožňuje zmínit všechny ty, kteří na poli kardiologie zaznamenali úspěchy a přispěli $\mathrm{k}$ pokroku a rozvoji československé a české kardiologie. Těm, kteří nejsou uvedeni, se tedy omlouváme a současně je možné tuto poznámku vzít jako výzvu pro další a nové autory, kteří budou mít zájem věnovat se sepsání podrobnější historie osmdesáti let naší odborné společnosti. 